\title{
Production of highly oxygenated organic molecules (HOMs) from trace contaminants during isoprene oxidation
}

\author{
Anne-Kathrin Bernhammer ${ }^{1,2}$, Lukas Fischer ${ }^{1}$, Bernhard Mentler $^{1}$, Martin Heinritzi $^{3}$, Mario Simon ${ }^{3}$, and \\ Armin Hansel ${ }^{1,2}$ \\ ${ }^{1}$ Institute for Ion and Applied Physics, University of Innsbruck, 6020 Innsbruck, Austria \\ ${ }^{2}$ IONICON Analytik GmbH, 6020 Innsbruck, Austria \\ ${ }^{3}$ Institute for Atmospheric and Environmental Sciences, Goethe University of Frankfurt, 60438 Frankfurt am Main, Germany
}

Correspondence: Armin Hansel (armin.hansel@uibk.ac.at)

Received: 12 December 2017 - Discussion started: 2 January 2018

Revised: 11 July 2018 - Accepted: 16 July 2018 - Published: 14 August 2018

\begin{abstract}
During nucleation studies from pure isoprene oxidation in the CLOUD chamber at the European Organization for Nuclear Research (CERN) we observed unexpected ion signals at $m / z=137.133\left(\mathrm{C}_{10} \mathrm{H}_{17}^{+}\right)$and $m / z=81.070$ $\left(\mathrm{C}_{6} \mathrm{H}_{9}^{+}\right)$with the recently developed proton-transfer-reaction time-of-flight (PTR3-TOF) mass spectrometer instrument. The mass-to-charge ratios of these ion signals typically correspond to protonated monoterpenes and their main fragment. We identified two origins of these signals: first secondary association reactions of protonated isoprene with isoprene within the PTR3-TOF reaction chamber and secondly $[4+2]$ cycloaddition (Diels-Alder) of isoprene inside the gas bottle which presumably forms the favored monoterpenes limonene and sylvestrene, as known from literature. Under our PTR3-TOF conditions used in 2016 an amount (relative to isoprene) of $2 \%$ is formed within the PTR3-TOF reaction chamber and $1 \%$ is already present in the gas bottle. The presence of unwanted cycloaddition products in the CLOUD chamber impacts the nucleation studies by creating ozonolysis products as the corresponding monoterpenes and is responsible for the majority of the observed highly oxygenated organic molecules (HOMs), which in turn leads to a significant overestimation of both the nucleation rate and the growth rate. In order to study new particle formation (NPF) from pure isoprene oxidation under relevant atmospheric conditions, it is important to improve and assure the quality and purity of the precursor isoprene. This was successfully achieved by cryogenically trapping lowervolatility compounds such as monoterpenes before isoprene was introduced into the CLOUD chamber.
\end{abstract}

\section{Introduction}

Emissions of biogenic volatile organic compounds (BVOCs) impact the oxidation capacity of the atmosphere and serve as precursors for secondary organic aerosols (SOAs) (Hallquist et al., 2009) through the formation of low-volatility oxidation products. They are emitted by a large variety of vegetation $\left(\sim 1150 \mathrm{Tg} \mathrm{C} \mathrm{yr}^{-1}\right)$. The most abundantly emitted BVOCs on a global scale are isoprene $(70 \%)$ and monoterpenes $(11 \%)$ (Guenther et al., 2012). These BVOCs serve as main gas-phase precursors for lower-volatility oxidation products that play a crucial role for SOA formation and have also been related to new particle formation (NPF) over forest regions in the presence of sulfuric acid (Hallar et al., 2011; Held et al., 2004; Pierce et al., 2014; Pryor et al., 2010; Riipinen et al., 2007; Yu et al., 2014).

It was shown that the oxidation of monoterpenes leads to the formation of highly oxygenated molecules (HOMs), some of which were termed extremely low-volatility organic compounds (ELVOCs) (Ehn et al., 2014; Jokinen et al., 2015). HOMs are formed via rapid autoxidation of $\mathrm{RO}_{2}$ radicals on the timescales of seconds. The highest ELVOC yields were found for limonene $\left(\mathrm{Y}_{3}\left(\mathrm{O}_{3}\right): 5.3 \%\right)$ and $\alpha$-pinene $\left(\mathrm{Y}\left(\mathrm{O}_{3}\right): 3.4 \%\right)$. The yield of isoprene was found to be only $0.03 \%(\mathrm{Y}(\mathrm{OH}))$, which is about 100 times less compared to $\alpha$-pinene (Jokinen et al., 2015). The autoxidation of $\mathrm{RO}_{2}$ radicals comprises intramolecular $\mathrm{H}$ shifts followed by rapid uptake of molecular oxygen, which forms another $\mathrm{RO}_{2}$ radical (Berndt et al., 2015). The highly oxygenated $\mathrm{RO}_{2}$ radicals can terminate either to monomers (mainly $\mathrm{C}_{10} \mathrm{H}_{14,16} \mathrm{O}_{7,9,11}$ ) or to dimers (mainly $\mathrm{C}_{20} \mathrm{H}_{30} \mathrm{O}_{8-16}$ and $\mathrm{C}_{19} \mathrm{H}_{28} \mathrm{O}_{7-11}$ ) (Ris- 
sanen et al., 2015). HOM formation is thought to be dominated by ozonolysis (Ehn et al., 2014; Jokinen et al., 2015); however, a recent study also showed significant HOM formation from $\mathrm{OH}$ reactions with monoterpenes (Berndt et al., 2016b). HOMs were shown to nucleate at atmospherically relevant concentrations even without sulfuric acid (Kirkby et al., 2016).

The oxidation of isoprene involves $\mathrm{OH}$-derived peroxyradical chemistry (Teng et al., 2017) and can lead to products with low vapor pressure that were shown to contribute to the formation of SOA (Krechmer et al., 2015; Berndt et al., 2016a). It was however observed in laboratory studies as well as in ambient measurements that the presence of isoprene inhibits NPF (Kiendler-Scharr et al., 2009; Kanawade et al., 2011; Lee et al., 2016). One hypothesis for this suppression was $\mathrm{OH}$ consumption by isoprene that leaves less $\mathrm{OH}$ for monoterpene reactions (Kiendler-Scharr et al., 2009). However, isoprene oxidation recycles $\mathrm{OH}$ at atmospheric conditions, which leads to undisturbed levels of $\mathrm{OH}$ over the Amazon basin when isoprene is present (Lelieveld et al., 2008, 2016; Kubistin et al., 2010; Taraborrelli et al., 2012). Thus, how isoprene oxidation influences monoterpene HOM formation is still unclear and was therefore investigated in the CLOUD chamber. From Jokinen et al. (2015) we know that tiny $(<1 \%)$ impurities of isoprene having a high HOM yield like monoterpenes could have a major impact on inferred yields of isoprene. During isoprene NPF studies in the CLOUD chamber, we detected unexpected ion signals at $m / z=137.133\left(\mathrm{C}_{10} \mathrm{H}_{17}^{+}\right)$and $m / z=81.070$ $\left(\mathrm{C}_{6} \mathrm{H}_{9}^{+}\right)$that are typically for monoterpenes, in addition to the expected protonated isoprene, with the recently developed high-resolution proton-transfer-reaction time-of-flight mass spectrometer (PTR3-TOF; Breitenlechner et al., 2017). Here we will explain and discuss the origin of these ion signals that are caused in part by low monoterpene contamination of isoprene. We will give an estimate of how the nucleation rate and the early growth rate are changed due to the presence of monoterpene contaminations. Installing a cryotrap in the isoprene supply line decreased the contamination as well as related oxidation products such as some $\mathrm{C}_{10}$ and all $\mathrm{C}_{15}$ and $\mathrm{C}_{20}$ HOMs significantly.

\section{Experimental}

\subsection{Instrumentation}

\subsubsection{PTR3-TOF}

In the present study a novel proton-transfer-reaction timeof-flight mass spectrometer (PTR-MS) called the PTR3TOF, which utilizes a new gas inlet and an innovative reaction chamber design was used, which is described in detail in Breitenlechner et al. (2017). The new reaction chamber consists of a tripole operated with RF (radio fre- quency) voltages generating an electric field only in the radial direction. An elevated electrical field is necessary to reduce clustering of primary hydronium $\left(\mathrm{H}_{3} \mathrm{O}^{+}\right)$and product ions with water molecules present in the sample gas. The PTR3-TOF was operated at $80 \mathrm{mbar}$ of pressure and a constant temperature of $38^{\circ} \mathrm{C}$ in the tripole reaction chamber. The RF amplitude was adjusted to $700-800 \mathrm{~V}_{p-p}$, which corresponds to an $E / N$ of typically $95 \mathrm{Td}$ ( $E$, electric field strength; $N$, number gas density; unit, townsend, Td; $1 \mathrm{Td}=10^{-17} \mathrm{~V} \mathrm{~cm}^{2}$ ). During the CLOUD 10 (autumn 2015) and CLOUD 11 (autumn 2016) campaigns the PTR3-TOF was regularly calibrated. For this purpose, known concentrations of isoprene, $\alpha$-pinene and hexanone from a gas standard (Apel-Riemer Environmental Inc., CO, USA) were diluted in $1 \mathrm{slpm}(1 \mathrm{slpm}=0.0000167$ standard cubic meter per second) zero air. Calibrations were performed for typical operating conditions of the CLOUD chamber: 38 and $85 \%$ relative humidity at $5{ }^{\circ} \mathrm{C}$. The instrumental background signal was determined by measuring chamber zero air. PTR3-TOF raw data were processed using newly developed software capable of high-resolution and multipeak analysis as described in Breitenlechner et al. (2017). Processed data were duty cycle corrected (Dcps, $\left.(i)=\operatorname{Cps}(i) \cdot \sqrt{101} / m_{i}\right)$, which compensates for mass-dependent transmission of the TOF mass spectrometer. The following sensitivities $(\varepsilon)$ were obtained at $5^{\circ} \mathrm{C}$ for a relative humidity of $85 \%$ for CLOUD 10 (2015) and for a relative humidity of $38 \%$ for CLOUD 11 (2016):

isoprene, $m / z=69.070 \quad\left(\mathrm{C}_{5} \mathrm{H}_{9}^{+}\right) ; \quad \varepsilon=980 \quad(2290)$ Dcps/ppbv at $38 \%$ (85\%) relative humidity, respectively.

$\alpha$-pinene, $\quad m / z=137.133 \quad\left(\mathrm{C}_{10} \mathrm{H}_{17}^{+}\right) ; \quad \varepsilon=$ 3500 (5440) Dcps ppbv $^{-1}$ at $38 \%$ (85\%) relative humidity, respectively.

3-hexanone, $m / z=101.0961\left(\mathrm{C}_{6} \mathrm{H}_{12} \mathrm{OH}^{+}\right) ; \varepsilon=17400$ (13900) $\mathrm{Dcpsppv}^{-1}$ at $38 \%(85 \%)$ relative humidity, respectively.

\subsubsection{CI-API-TOF}

The chemical ionization atmospheric-pressure-interface time-of-flight mass spectrometer (nitrate CI-API-TOF, Tofwerk AG, Thun, Switzerland) uses an ion source similar to the design of Eisele and Tanner (1993), although, instead of a radioactive source, a corona discharge is used to generate primary nitrate ions $\mathrm{NO}_{3}^{-}\left(\mathrm{HNO}_{3}\right)_{0-2}$ (Kürten et al., 2011). The instrument was calibrated with respect to sulfuric acid (Kürten et al., 2012) and for the mass-dependent transmission efficiency (Heinritzi et al., 2016). For detailed information on the quantification of highly oxygenated organic molecules, the reader is referred to Kirkby et al. (2016).

\subsubsection{Cryotrap}

A cryotrap was added to the isoprene gas supply line directly behind the gas bottle to freeze out possible lower-volatility contaminations and effectively remove impurity compounds 

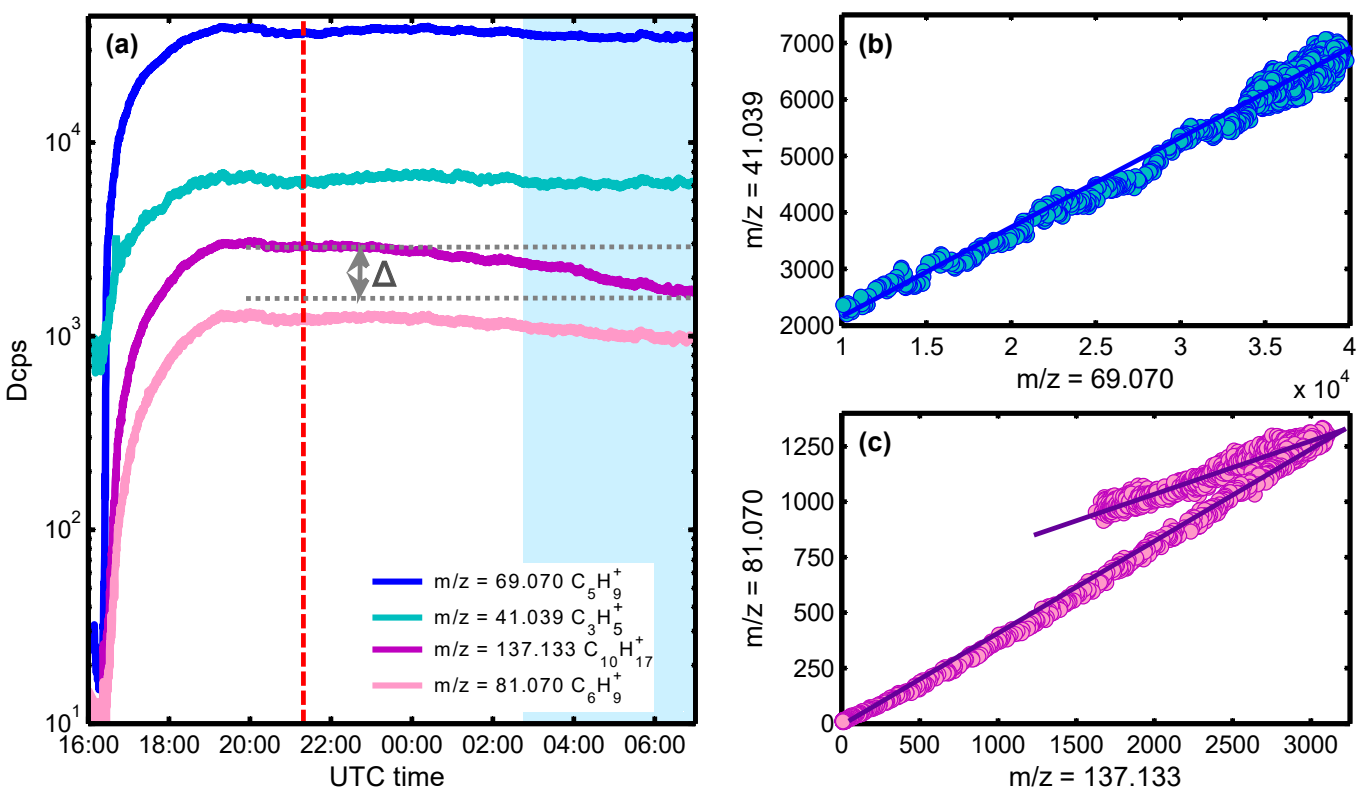

Figure 1. (a) Time series of isoprene observed at the protonated mass $m / z=69.070$, its main fragment at $m / z=41.039$, sum of isoprene cluster and monoterpenes $(m / z=137.133)$ and their main fragment $(m / z=81.070)$ during the 2016 experiment. The blue shaded area corresponds to times with the cryotrap switched on; the dashed red line indicates the start of $\mathrm{O}_{3} ; \Delta$ marks the signal loss caused by ozonolysis and cryotrap freeze-out. (b) Correlation plot of $\mathrm{m} / z=69.070$ and its main fragment $\mathrm{m} / z=41.039$; (c) correlation plot of $\mathrm{m} / z=137.133$ and its main fragment $m / z=81.070$.

like monoterpenes or higher oxidized organics. The cryotrap consisted of a chiller coil placed inside a $100 \mathrm{~mm}$ diameter dewar flask filled with Huber DW-Therm thermofluid. The chiller maintained the liquid at $-57.6^{\circ} \mathrm{C}$. Surrounding the chiller coil and immersed in the dewar liquid was a second spiral coil with six rings of $85 \mathrm{~mm}$ diameter through which the gas passed straight from the isoprene bottle (maximum flow of $10 \mathrm{sccm}$, average flow rate of $5 \mathrm{sccm}$ ). The dewar flask was positioned upstream of the isoprene mass flow controller (MFC). The isoprene coil was of a 6 and $4 \mathrm{~mm}$ diameter (OD and ID, respectively) electropolished stainless steel and was thoroughly cleaned before use. The total length of the gas pipe inside the dewar flask was approximately $1.8 \mathrm{~m}$. The cryotrap was in use for a total of 14 days of measurement time.

\subsection{Experimental procedures}

\subsubsection{Chamber experiments}

Measurements were carried out in the CLOUD (Cosmics Leaving OUtdoor Droplets) chamber at the European Organization for Nuclear Research (CERN) (Duplissy et al., 2016; Kirkby et al., 2011) during the CLOUD 10 campaign in autumn 2015 and the CLOUD 11 campaign in autumn 2016. Experiments at the CLOUD chamber are generally carried out in a continuous and dynamical manner instead of separate experiments in "batch" mode.
During nucleation studies of pure isoprene over the course of the CLOUD 10 campaign in 2015, $13.5 \mathrm{ppbv}$ of isoprene (1\% isoprene in $\mathrm{N}_{2}$, purity $99.8 \%$, Carbagas AG) was introduced into the chamber. Ozone ( $45 \mathrm{ppbv}$ ) was introduced approximately $10 \mathrm{~h}$ after conditioning the chamber in two steps for an additional $9.5 \mathrm{~h}$. The experiment was carried out at $85 \%$ relative humidity and $5{ }^{\circ} \mathrm{C}$. Additional experiments were conducted during the CLOUD 11 campaign in 2016, this time with a cryotrap added to the isoprene supply line. For this purpose, $33.5 \mathrm{ppbv}$ of isoprene was injected into the chamber, and ozone ( $35 \mathrm{ppbv}$ ) was added $5 \mathrm{~h}$ later. After a reaction time of $5.5 \mathrm{~h}$ the cryotrap was activated to remove low-volatility contaminants and measurements continued for another $4 \mathrm{~h}$. This experiment was carried out at $37 \%$ relative humidity and $6{ }^{\circ} \mathrm{C}$. Gas-phase precursors were measured with the PTR3-TOF. Simultaneously, a nitrate CI-APITOF mass spectrometer was used to analyze the highly oxygenated organic compounds from ozonolysis experiments.

\subsubsection{Cryotrap evaporation experiment}

After a total of 2 weeks of operation, the cryotrap was disconnected from the chamber system and directly connected to the PTR3-TOF inlet. A steady stream of dry $\mathrm{N}_{2}$ (3 slpm) was fed through the isoprene coil. After a baseline determination, the spiral coil was removed from the chiller liquid and allowed to warm up from $-57.6^{\circ} \mathrm{C}$ to room temperature over a period of $3 \mathrm{~h}$. The concentrations of released organic com- 
pounds were measured with the PTR3-TOF. After $45 \mathrm{~min}$ an additional $1: 2$ dilution with dry $\mathrm{N}_{2}$ became necessary due to a rapid depletion of primary ions.

\section{Result and discussion}

Figure 1a shows the temporal behavior of the ion signals at $m / z=69.070\left(\mathrm{C}_{5} \mathrm{H}_{9}^{+}\right)$and $m / z=41.039\left(\mathrm{C}_{3} \mathrm{H}_{5}^{+}\right)$, corresponding to protonated isoprene and its fragment, during the 2016 experiment. After isoprene concentrations reached a steady level of $\sim 33.5 \mathrm{ppbv}$, ozone ( $\sim 35 \mathrm{ppbv})$ was continuously injected, and the cryotrap was switched on after several hours of oxidation to freeze out possible low-volatility contaminants whose presence was suspected in 2015. As expected, the ion signals at $\mathrm{m} / z=69.070$ and $\mathrm{m} / z=41.039$ were linearly correlated over the entire course of the experiment, independent of experimental conditions, consistent with fragment formation inside the PTR3-TOF instrument (Fig. 1b).

We observed additional ion signals at $\mathrm{m} / z=137.133$ $\left(\mathrm{C}_{10} \mathrm{H}_{17}^{+}\right)$and $m / z=81.070\left(\mathrm{C}_{6} \mathrm{H}_{9}^{+}\right)$when isoprene was added. These ion signals correspond to typical mass-tocharge ratios of protonated monoterpenes and the corresponding fragment ion. Contrary to the isoprene signal, the ion signals at both $m / z=137.133$ and $m / z=81.070$ show dependence on ozone and a decrease induced by the cryotrap. Using the sensitivity from the $\alpha$-pinene calibration for the signal at $m / z=137.133$ (volume mixing ratio, VMR) $[\mathrm{ppbv}]=\mathrm{Dcps} / \varepsilon ; \varepsilon=$ sensitivity obtained from calibration), about $1 \mathrm{ppbv}$ of $\alpha$-pinene or other monoterpenes was observed. This amount is equivalent to $3 \%$ of the measured isoprene ( $33.5 \mathrm{ppbv}$ ). Correlation of $\mathrm{m} / z=81.070$ and $m / z=137.133$ shows two slopes, which, in turn, hints at two different sources for the $\mathrm{C}_{10} \mathrm{H}_{17}^{+}$signal observed with PTR3TOF (Fig. 1c).

We explain the formation of the monoterpene signal $\left(\mathrm{C}_{10} \mathrm{H}_{17}^{+}\right)$, on the one hand, with secondary association reactions of protonated isoprene with isoprene within the PTR3TOF reaction chamber forming $\mathrm{C}_{10} \mathrm{H}_{17}^{+}$ions. As will be shown below, this route accounts for two-thirds of the total signal detected at $m / z=137.133$, which is equivalent to $2 \%$ relative to the isoprene signal. On the other hand, one-third of the total $\mathrm{C}_{10} \mathrm{H}_{17}^{+}$signal or $1 \%$ (relative to isoprene) is attributed to dimerization of isoprene (Estevez et al., 2014, and references therein) inside the gas bottle, which forms [4+2] cycloaddition products. The amount of dimerization inside the gas bottle was estimated from a chamber experiment during which the cryotrap was switched off at the beginning and then turned on for the last hours of the measurement. The amount of cycloaddition product is equal to the difference, $\Delta$, between the maximum concentration before ozone injection and the decrease due to oxidation by ozone and freezeout caused by the cryotrap (Fig. 1a).

\subsection{Secondary association reactions within the PTR3-TOF reaction chamber}

Figure $2 \mathrm{a}$ shows the temporal behavior of the ion signals at $m / z=137.133\left(\mathrm{C}_{10} \mathrm{H}_{17}^{+}\right), m / z=81.070\left(\mathrm{C}_{6} \mathrm{H}_{9}^{+}\right)$and $m / z=273.258\left(\mathrm{C}_{20} \mathrm{H}_{33}^{+}\right)$monitored during the warm-up of the cryotrap during an experiment at the end of the 2016 campaign after 2 weeks of freezing out the low-volatility impurities of the isoprene. Immediately after removal of the spiral coil from the cooling liquid, we observed signals at all three mass-to-charge ratios. At a first glance their temporal behavior seems to be identical, but a closer look at the correlations reveals significant differences. The protonated monoterpene at $m / z=137.133$ and its fragment at $m / z=81.070$ show a linear dependency (Fig. 2b), which is expected from ion fragmentation within the PTR3-TOF following pseudo firstorder kinetics among $\mathrm{H}_{3} \mathrm{O}^{+} \cdot\left(\mathrm{H}_{2} \mathrm{O}\right)_{n}(n=0-2)$ primary ions in reactions with the reactant $\mathrm{C}_{10} \mathrm{H}_{16}$ (1).

$$
\begin{aligned}
\mathrm{H}_{3} \mathrm{O}^{+}\left(\mathrm{H}_{2} \mathrm{O}\right)_{n}+\mathrm{C}_{10} \mathrm{H}_{16} & \rightarrow \mathrm{C}_{10} \mathrm{H}_{17}^{+}+(n+1) \mathrm{H}_{2} \mathrm{O} \\
& \rightarrow \mathrm{C}_{6} \mathrm{H}_{9}^{+}+\mathrm{C}_{4} \mathrm{H}_{8}+(n+1) \mathrm{H}_{2} \mathrm{O}
\end{aligned}
$$

Comparison of $\mathrm{m} / z=137.133$ and $\mathrm{m} / \mathrm{z}=273.258$, however, reveals a quadratic dependency (Fig. 2c) and indicates that $\mathrm{C}_{20} \mathrm{H}_{33}^{+}$is the product of the secondary association reaction of $\mathrm{C}_{10} \mathrm{H}_{17}^{+}$with $\mathrm{C}_{10} \mathrm{H}_{16}$ stabilized in collisions with $\mathrm{M}$ in the PTR3-TOF reaction chamber (2).

$\mathrm{C}_{10} \mathrm{H}_{17}^{+}+\mathrm{C}_{10} \mathrm{H}_{16}+M \rightarrow \mathrm{C}_{10} \mathrm{H}_{17}^{+}\left(\mathrm{C}_{10} \mathrm{H}_{16}\right)+M$

Contrary to a classical proton-transfer-reaction time-of-flight mass spectrometer (PTR-TOF-MS) (Graus et al. 2010), the PTR3-TOF operates at a much higher pressure $(80 \mathrm{mbar})$ and at a longer reaction time $(3 \mathrm{~ms})$. This leads to a significant increase in ion molecule collisions inside the reaction zone of the PTR3-TOF, which enables secondary association reactions to become visible at reactant concentrations of about $10 \mathrm{ppbv}$ compared to $10 \mathrm{ppmv}$ in classical PTR-MS (Hansel et al., 1995).

The results shown in Fig. 2 demonstrate that monoterpenes are released from the spiral coil during warm-up. This means that monoterpene contaminants were present in the isoprene gas bottle.

In Fig. 3 we compare the correlation of $m / z=137.133$ with $m / z=69.070$ (Fig. 3a and c) obtained during chamber experiments in 2016 without the cryotrap and before ozone injection and the correlation of $\mathrm{m} / z=273.258$ with $m / z=137.133$ (Fig. $3 b$ and d) obtained during cryotrap evaporation experiments in 2016. While the correlations of $m / z=273.258$ with $m / z=137.133$ in Fig. 3b and $\mathrm{d}$ show a clear quadratic dependence, the correlation of $m / z=137.133$ with $m / z=69.070$ in Fig. 3a seems to indicate two overlapping processes: a quadratic one from the secondary association reaction and an additional linear process. A closer look at the lower concentration range in which secondary association reaction is not yet dominant reveals that 

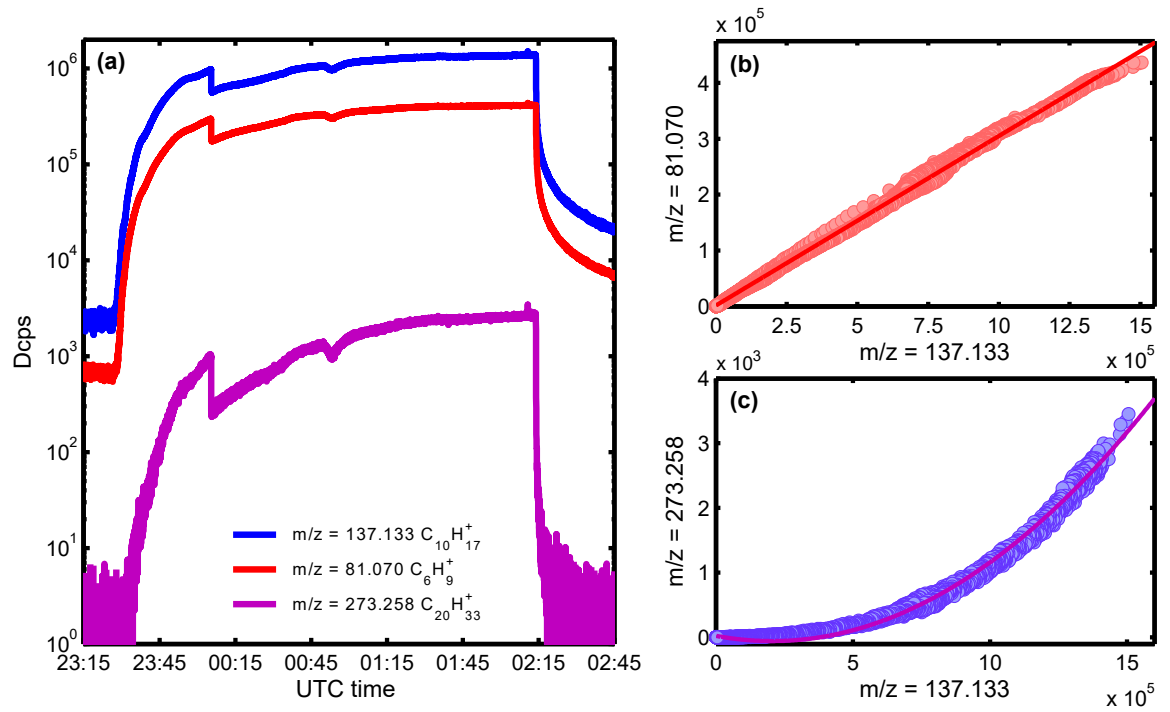

Figure 2. (a) Time series of $m / z=137.133\left(\mathrm{C}_{10} \mathrm{H}_{17}^{+}\right), m / z=81.070\left(\mathrm{C}_{6} \mathrm{H}_{9}^{+}\right)$and $m / z=273.258\left(\mathrm{C}_{20} \mathrm{H}_{33}^{+}\right)$during the cryotrap evaporation experiment (2016). (b) Correlation plot of $m / z=137.133\left(\mathrm{C}_{10} \mathrm{H}_{17}^{+}\right)$and its main fragment $m / z=81.070\left(\mathrm{C}_{6} \mathrm{H}_{9}^{+}\right)$. (c) Correlation plot of $m / z=137.133\left(\mathrm{C}_{10} \mathrm{H}_{17}^{+}\right)$and the secondary ionic cluster $m / z=273.258\left(\mathrm{C}_{20} \mathrm{H}_{33}^{+}\right)$.
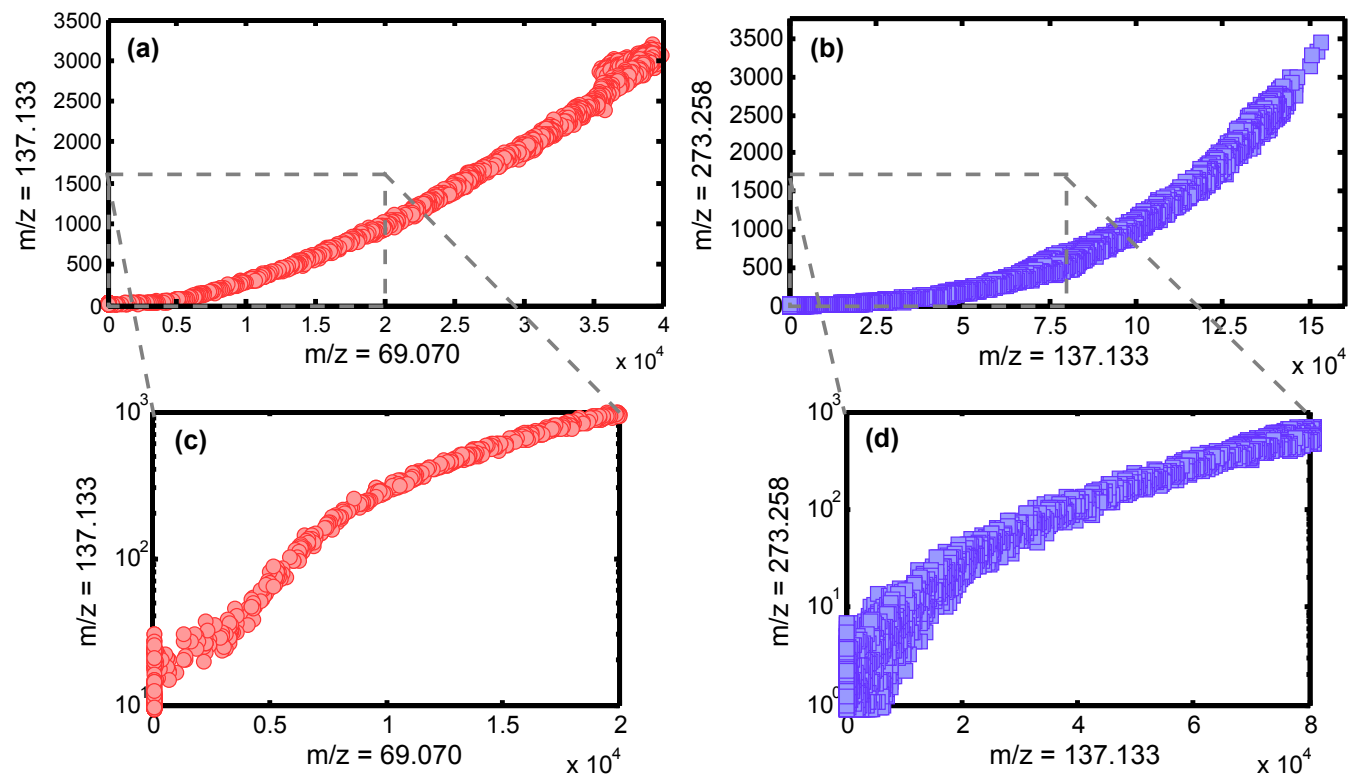

Figure 3. Comparison of the correlation plots of the 2016 chamber experiment (a) and 2016 evaporation experiment (b) for $m / z=69.070$ vs. $m / z=137.133$ (red) and $m / z=137.133$ vs. $m / z=273.258$ (purple). Panel (a) shows the correlation over the initial chamber experiment without the cryotrap and before the addition of ozone. Panel (b) shows the correlation over the entire evaporation experiment. Panels (c) and (d) focus on the lower concentration range. For the pure secondary association reaction (b, d) a clear quadratic dependency is observed, while for the chamber experiment (a, c) two overlapping processes - especially in the lower concentration regime - take place before the cluster formation becomes the dominant pathway at higher concentrations.

this is indeed the case (Fig. 3c). Therefore, we identify two processes that create the observed signal at $m / z=137.133$.
The first is a secondary association reaction within the PTR3-TOF reaction chamber:

$$
\mathrm{H}_{3} \mathrm{O}^{+}\left(\mathrm{H}_{2} \mathrm{O}\right)_{n}+\mathrm{C}_{5} \mathrm{H}_{8} \longrightarrow \mathrm{C}_{5} \mathrm{H}_{9}^{+}+(n+1) \mathrm{H}_{2} \mathrm{O}
$$


$\mathrm{C}_{5} \mathrm{H}_{9}^{+}+\mathrm{C}_{5} \mathrm{H}_{8}+M \longrightarrow \mathrm{C}_{10} \mathrm{H}_{17}^{+}+M$.

The second is direct ionization of $\mathrm{a}_{10}$ precursor:

$\mathrm{H}_{3} \mathrm{O}^{+}\left(\mathrm{H}_{2} \mathrm{O}\right)_{n}+\mathrm{C}_{10} \mathrm{H}_{16} \longrightarrow \mathrm{C}_{10} \mathrm{H}_{17}^{+}+(n+1) \mathrm{H}_{2} \mathrm{O}$.

\subsection{Dimerization inside the gas bottle}

Dimerization of pure isoprene is known to occur when stored without a stabilizer $\left(0.000017 \% \mathrm{~h}^{-1}\right.$ at $20^{\circ} \mathrm{C}$; Estevez et al., 2014, and reference therein). It is influenced by pressure and temperature and proceeds via a [4+2] cycloaddition with isoprene acting as both diene and dienophile. This reaction can explain the observed compound at $m / z=137.133$ and $m / z=81.070\left(\mathrm{C}_{6} \mathrm{H}_{9}^{+}\right)$. Cycloaddition of isoprene has been well documented (Citroni et al., 2007; Compton et al., 1976; Estevez et al., 2014; Groves and Lehrle, 1992; Walling and Peisach, 1958), and thermally induced polymerization in the gas phase has recently been shown for heated gas chromatography inlets. The dimerization leads predominantly to six-membered rings, mainly the [4+2] Diels-Alder products sylvestrene and limonene (Estevez et al., 2014, and references therein). This known dimerization is the reason for the addition of $p$-tert-butylcatechol (TBC) to the liquid isoprene (Sigma Aldrich, 99.8\% purity, with addition of $139 \mathrm{ppm}$ TBC), which was used for creation of the gas standard provided by the supplier. The stabilizer itself could not be detected by PTR3-TOF due to an interference with major monoterpene oxidation products $\left(\mathrm{C}_{10} \mathrm{H}_{14} \mathrm{O}-\mathrm{H}^{+}\right)$. Additionally, liquid isoprene may already contain up to $2000 \mathrm{ppm}$ of isoprene dimers upon purchase, as stated in the product specification, which is also the case for liquid phase isoprene that is more commonly used as a precursor source in isoprene experiments.

Despite the addition of TBC as a stabilizer to prevent polymerization inside the gas bottle (stainless steel, 2 years old in $2016), 1 \%$ of dimerized isoprene ( $350 \mathrm{pptv}$ ) could be observed at $m / z=137.133$ in 2016 . The monoterpenes could not be conclusively identified due to sole measurement of molecular formulas. But they are presumably the favored cycloaddition products sylvestrene and limonene (Wang et al., 2013). The presence of monoterpenes in the gas bottle was confirmed by gas chromatography and mass spectrometry (GC-MS) analysis performed in summer 2016 (Ugo Molteni, PSI, private communication, 2016). Nine different monoterpene isomers could be detected. Unfortunately, no monoterpene standards which would allow the identification of the individual monoterpene isomers were used.

These monoterpenes have much lower vapor pressures than isoprene and can effectively be removed from the system by the cryotrap (Fig. 1a). We found that the ratio between the total ion signal at $m / z=137.133$ (sum of cycloaddition product from the gas bottle and from secondary ion cluster formation) and isoprene changed from the autumn 2015 campaign (CLOUD 10) and the autumn 2016 campaign (CLOUD
11). It doubled over the course of a year, presumably due to a depletion of the stabilizer and increased dimerization of the isoprene precursor from $1.5 \%$ to a total of $3 \%$.

\subsection{Impact of impurities}

Due to the presence of double bonds, isoprene and especially monoterpenes show a high reactivity towards ozone. The reaction rate of $d$-limonene with ozone is even faster $\left(21.1 \times 10^{-17} \mathrm{~cm}^{3}\right.$ molecule $\left.{ }^{-1} \mathrm{~s}^{-1}\right)$ than the corresponding reaction rate of $\alpha$-pinene $\left(9.4 \times 10^{-17} \mathrm{~cm}^{3}\right.$ molecule $\left.{ }^{-1} \mathrm{~s}^{-1}\right)$ and both are significantly faster than the one of isoprene $\left(1.3 \times 10^{-17} \mathrm{~cm}^{3}\right.$ molecule ${ }^{-1} \mathrm{~s}^{-1}$ at $298 \mathrm{~K}$; Khamaganov and Hites, 2001). However, it is convenient to assume that the reaction rate of sylvestrene is also similar to that of limonene considering the structural similarity of limonene (methyl group in meta-position instead of para-position). The high reaction rates with ozone make the contaminants ideal candidates to significantly influence the distribution of the resulting oxidation products even at comparatively low concentrations.

The distribution of oxidation products after ozone exposure and, more importantly after cryotrap freeze-out of the low-volatility precursors, was investigated during the 2016 CLOUD measurements.

Figure 4 shows a comparison of selected oxidation products from isoprene ozonolysis and monoterpene ozonolysis as observed during CLOUD experiments. The respective oxidation products from isoprene ozonolysis are easily distinguishable from oxidation products of the monoterpenes. Figure 4 a shows oxidation products originating from isoprene as a precursor. The compounds show a significant increase upon ozone exposure but are not affected by the cryotrap due to the high vapor pressure of the precursor. Instead they continue to increase until steady-state concentrations are reached. The picture for oxidation products from monoterpene ozonolysis is different. A similar increase after ozone exposure can be observed. However, due to the lower vapor pressure of the precursors, deployment of the cryotrap leads to a decrease in the respective signals of the oxidation products as the precursors are frozen out by the cryotrap and are no longer available for oxidation (Fig. 4b).

Due to the different temporal behavior, discrimination among the respective oxidation products is comparatively simple and shows that despite significantly lower concentrations of the low-volatility precursor, at least one-third of the more than 200 identified signals with $\mathrm{H}_{3} \mathrm{O}^{+} \cdot\left(\mathrm{H}_{2} \mathrm{O}\right)_{n}$ as primary reagent ions (up to $m / z=350$ ) show the behavior of monoterpene oxidation products. Not only the major monoterpene oxidation products shown in Fig. $4 \mathrm{~b}$ show this significant decrease upon deployment of the cryotrap but also the HOMs as shown in Fig. 4c for total HOM concentration and its main contributors $\mathrm{C}_{10} \mathrm{H}_{14} \mathrm{O}_{9}, \mathrm{C}_{10} \mathrm{H}_{14} \mathrm{O}_{7}$ and $\mathrm{C}_{10} \mathrm{H}_{16} \mathrm{O}_{7}$. The total raw signals for monoterpene oxidation products are smaller than for isoprene oxidation products but 

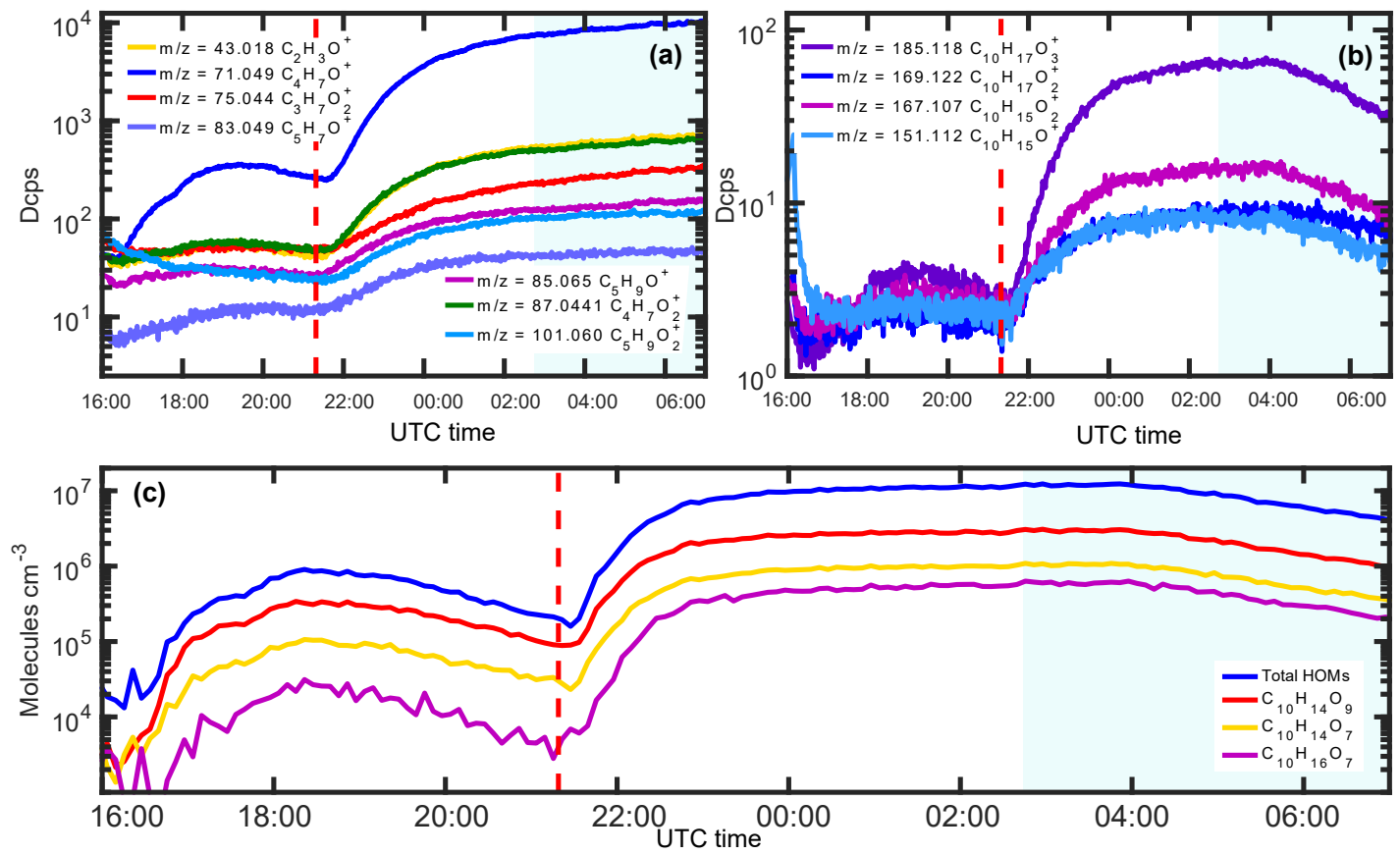

Figure 4. (a) Time series of selected pure isoprene oxidation products in 2016. (b) Time series of main monoterpene-analogue oxidation products which show a typical decrease towards the end due to a removal of the precursor with the cryotrap while the isoprene products are not affected. (c) Time series of total HOMs and the three major contributors $\left(\mathrm{C}_{10}\right.$ compounds) to the total signal. The red dashed line corresponds to the injection time of ozone and the blue shaded area to the times with the cryotrap.

concentrations are still in the parts per trillion by volume range for a given injection of $33.5 \mathrm{ppbv}$ of isoprene with $1 \%$ of monoterpene contamination relative to isoprene concentrations.

The effect of the cryotrap on the oxidation product distribution was not only observed by means of PTR3-TOF but also by means of CI-API-TOF mass spectrometry. Figure 5 shows a mass defect plot comparing HOMs before and during the deployment of the cryotrap using CI-APITOF data from 2016. Unfortunately, steady state could not be reached for the freeze-out of the monoterpenes, so monoterpene oxidation products remain visible. It takes $3 \mathrm{~h}$ to exchange the gases in the CLOUD chamber, meaning that after starting to completely remove the monoterpenes from the isoprene supply line, $3 \mathrm{~h}$ later $63 \%$ of the original steadystate monoterpene concentration is still present. Nevertheless, the impact of the partial removal of the monoterpene impurities is clearly visible.

Removal of the monoterpene contaminants leads to a significant decrease in signal intensity and complete disappearance of the heavier masses. $\mathrm{C}_{10}$ compounds appear prominently as the dominating species, with $\mathrm{C}_{10} \mathrm{H}_{14} \mathrm{O}_{9}$ as the predominant compound. Without an active cryotrap, $\mathrm{C}_{15} \mathrm{H}_{24} \mathrm{O}_{\mathrm{x}}$ and $\mathrm{C}_{20} \mathrm{H}_{30} \mathrm{O}_{\mathrm{x}}$ signals are also clearly visible (Fig. 5a). Comparison of the HOM spectra shows a complete disappearance of the $\mathrm{C}_{15}$ and $\mathrm{C}_{20}$ bands upon deployment of the cryotrap and also some $\mathrm{C}_{10}$ compounds are significantly reduced, as can be seen in Fig. 5 b. $\mathrm{C}_{2} \mathrm{H}_{5} \mathrm{O}_{3}$ becomes the predominant compound after freeze-out. This clearly indicates a significant change in the observed oxidation products and shows how strongly trace contaminations of reactive $\mathrm{C}_{10}$ compounds, even at low concentrations, can impact HOM distribution from isoprene ozonolysis. This is due to the capability of monoterpenes to form HOMs with high yield and, to a certain degree, an interference between the oxidation mechanism of isoprene and monoterpenes since both mechanisms revolve around $\mathrm{RO}_{2}$ chemistry (Teng et al., 2017; Rissanen et al., 2015), which could affect the resulting closed-shell HOM distribution. In a recent paper, Berndt et al. (2018a) describe the formation of dimers (HOMs) with (fast) accretion product formation from peroxy radicals: $\mathrm{RO}_{2}+\mathrm{R}^{\prime} \mathrm{O}_{2}->\mathrm{ROOR}^{\prime}$ $+\mathrm{O}_{2}$. The reactivity of this reaction path increases with increasing functionalization of the $\mathrm{RO}_{2}$ radicals. The highest accretion rate constants were observed for $\mathrm{RO}_{2}$ radicals bearing a hydroxyl and an endoperoxide group in addition to the peroxy moiety. Analogously, having isoprene $\left(\mathrm{C}_{5}\right)$ contaminated with monoterpenes $\left(\mathrm{C}_{10}\right)$ could explain the fast formation of $\mathrm{C}_{15}$ compounds from $\mathrm{C}_{5}-\mathrm{RO}_{2}+\mathrm{C}_{10}-\mathrm{RO}_{2}$ accretion reactions. $\mathrm{C}_{10}$ closed-shell $\mathrm{HOMs}$ are produced either by direct oxidation of $\mathrm{C}_{10}$ contaminants or by $\mathrm{C}_{5}-\mathrm{RO}_{2}$ "self-reactions". In an additional paper Berndt et al. (2018b) describe in detail the mechanism of product formation from $\alpha$-pinene oxidation under the influence of isoprene. The impact of the $\mathrm{C}_{10}$ contaminants is most prominently visible in 

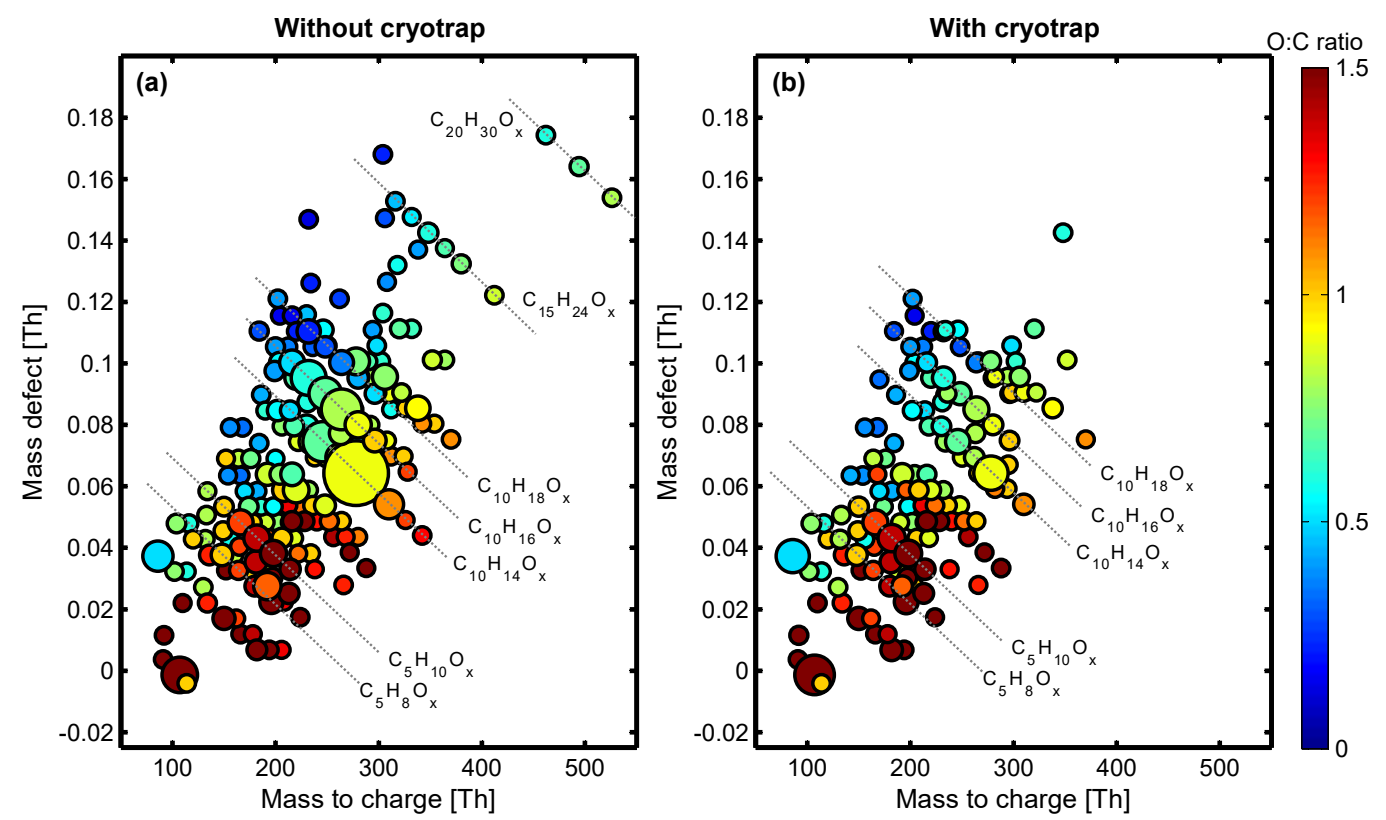

Figure 5. Mass defect plot obtained from 2016 CI-API-TOF data after subtraction of primary ions $\left(\mathrm{NO}_{3}^{-}\left(\mathrm{HNO}_{3}\right)_{0-2}\right)$ for $(\mathbf{a})$ isoprene ozonolysis without a cryotrap and (b) isoprene ozonolysis with a cryotrap. The circle size corresponds to the signal intensity. Steady state was not reached for the measurements with the cryotrap; therefore cryogenic removal was incomplete and oxidation products from the monoterpene oxidation are still visible. Nevertheless, a significant decrease in signal intensities, especially in the $\mathrm{C}_{10}$ range, can be observed.

the significant decrease in $\mathrm{C}_{10}$ compounds and the disappearance of $\mathrm{C}_{15}$ and $\mathrm{C}_{20}$ compounds upon activation of the cryotrap as shown in Fig. $5 \mathrm{~b}$ in which the mentioned formation pathway via accretion reactions is no longer feasible and fewer HOMs are formed.

Earlier studies have already argued that not all HOMs measured by the nitrate CI-API-TOF mass spectrometer possess extremely low volatility (Kurten et al., 2016; Tröstl et al., 2016). While a large fraction of $\mathrm{C}_{10}$ class molecules may be low-volatility organic compounds or even semivolatile organic compounds, basically all $\mathrm{C}_{20}$ molecules fall into the extremely low-volatility category, which is suspected to be the most relevant for nucleation and early growth. We can thus assume with some certainty that a missing cryotrap, which leads to unintended $\mathrm{C}_{20} \mathrm{HOM}$ formation, directly increases measured nucleation rates and early growth of particles. We estimated the effect on nucleation and growth by quantifying the resulting HOMs with and without an active cryotrap and related them to nucleation rates according to Kirkby et al. (2016) and growth rates according to Tröstl et al. (2016).

The comparison for nucleation rate shows that without a cryotrap we have a total HOM concentration of $1.2 \times 10^{7} \mathrm{~cm}^{-3}$, which would result in an approximate nucleation rate $J$ of $6.5 \mathrm{~cm}^{-2} \mathrm{~s}^{-1}$. With an active cryotrap, total HOM concentration is reduced to $2.6 \times 10^{6} \mathrm{~cm}^{-3}$, which results in a nucleation rate $J$ of $1.5 \times 10^{-3} \mathrm{~cm}^{-3} \mathrm{~s}^{-1}$. Performing nucleation experiments without a cryotrap would lead to an overestimation of $J$ by a factor of 43 . Thus, isoprene would wrongly be considered as a molecule that is capable of producing pure biogenic nucleation at atmospherically relevant concentrations, while in reality it is not.

Comparison for growth rates using the parameterization from Tröstl et al. (2016) for particles in the $1.7-3 \mathrm{~nm}$ range and an assumed particle size of $3 \mathrm{~nm}$ shows a growth rate of $1.5 \mathrm{~nm} \mathrm{~h}^{-1}$ without an active cryotrap and a growth rate of $0.2 \mathrm{~nm} \mathrm{~h}^{-1}$ with an active cryotrap. Hence performing growth experiments without a cryotrap would lead to an overestimation of growth rates by approximately an order of magnitude. Thus, isoprene would be attributed with possessing a much larger influence on early particle growth while in truth a significant fraction of growth is caused by oxidation products from the contaminants.

\section{Conclusion}

We have observed unexpected ion signals at $m / z=137.133$ and $m / z=81.070$ during pure isoprene oxidation experiments which correspond to monoterpene signals. The sources of these signals were attributed to a secondary association reaction between protonated isoprene and isoprene in the PTR3-TOF (two-thirds of total signal) and, more significantly, monoterpenes caused by dimerization of isoprene inside the gas bottle (one-third of total signal). While the first result is important for the growing group of PTR3-TOF users, the latter result is important for a much greater group of atmospheric scientists. Isoprene dimer contamination of 
$2000 \mathrm{ppm}$ is stated by Sigma-Aldrich for their liquid isoprene with purity $\geq 99 \%$. Dimerization of isoprene leads to compounds identical to monoterpenes in structure and chemical behavior. The presence of reactive monoterpenes significantly impacts the oxidation product distribution. The overall effect of the contaminants has been clearly shown in the mass defect plot. The disappearance of higher masses, especially in the $\mathrm{C}_{15}$ to $\mathrm{C}_{20}$ range upon deployment of a cryotrap, has a profound impact on nucleation rates and growth rates. An overestimation of - in our case - at least 1 order of magnitude may thus lead to a misinterpretation of resulting data and their atmospheric implications due to attribution of properties to isoprene that the compound does not in reality possess and are caused by the lower-volatility contaminants.

Results of this study, fortunately, do not affect previous CLOUD results as none of them pertain to isoprene effects on nucleation or growth. However, future isoprene studies at the CLOUD chamber will take these findings fully into account and use only data that were obtained with a cryotrap installed in the isoprene supply line. The first CLOUD study involving isoprene oxidation makes use of the cryotrap to clean isoprene from monoterpene contaminations.

The findings of the present work can be extended to experiments using evaporation of liquid isoprene as a precursor source. Evaporation of liquid isoprene requires active heating (Dommen et al., 2009), which, unless very carefully controlled, may lead to an increased polymerization within the source liquid as well as an enhanced evaporation of contaminants into the experimental chamber. As has been shown in this study, it is therefore of vital importance to assure purity of the isoprene precursor when assessing HOM formation, nucleation and growth. Otherwise the influence of lower-volatility contaminants on experimental results cannot be ruled out and may lead to misinterpretation of actual atmospheric implications. The required proper precursor control needed to achieve conclusive results can successfully be achieved via deployment of a cryotrap upstream of the experimental chamber, for example, as demonstrated in this study.

Data availability. Data related to this article are available on request addressed to the corresponding author.

Author contributions. $\mathrm{AKB}$ and $\mathrm{LF}$ and $\mathrm{BH}$ did the measurements and data analysis of PTR3 experiments at CLOUD. MH and MS contributed with HOM data obtained with the CI-API-TOF at CLOUD. AKB and AH wrote the manuscript and all authors contributed to the final manuscript development.

Competing interests. The authors declare that they have no conflict of interest.
Acknowledgements. We would like to thank CERN for supporting CLOUD with important technical and financial resources, and for providing a particle beam from the CERN Proton Synchrotron. We also thank Albin Wasem (CERN) and Serge Mathot (CERN) for designing and constructing the cryotrap. This research has received funding from the EC Seventh Framework Programme (Marie Curie Initial Training Network "CLOUD-TRAIN" no. 316662) and the Austrian Research Funding Association (FFG, project number 846050).

Edited by: Bin Yuan

Reviewed by: five anonymous referees

\section{References}

Berndt, T., Richters, S., Kaethner, R., Voigtländer, J., Stratmann, F., Sipilä, M., Kulmala, M., and Herrmann, H.: GasPhase Ozonolysis of Cycloalkenes: Formation of Highly Oxidized $\mathrm{RO}_{3}$ Radicals and Their Reactions with $\mathrm{NO}, \mathrm{NO}_{2}, \mathrm{SO}_{2}$, and Other $\mathrm{RO}_{3}$ Radicals, J. Phys. Chem., 119, 10336-10348, https://doi.org/10.1021/acs.jpca.5b07295, 2015.

Berndt, T., Herrmann, H., Sipilä, M., and Kulmala, M.: Highly Oxidized Second-Generation Products from the Gas-Phase Reaction of OH Radicals with Isoprene, J. Phys. Chem., 120, 10150 10159, https://doi.org/10.1021/acs.jpca.6b10987, 2016a.

Berndt, T., Richters, S., Jokinen, T., Hyttinen, N., Kurtén, T., Otkjær, R. V., Kjaergaard, H. G., Stratmann, F., Herrmann, H., Sipilä, M., Kulmala, M., and Ehn, M.: Hydroxyl radicalinduced formation of highly oxidized organic compounds, Nature Comm., 7, 13677, https://doi.org/10.1038/ncomms13677, 2016b.

Berndt, T., Scholz, W., Mentler, B., Fischer, L., Herrmann, H., Kulmala, M., and Hansel, A., Accretion product formation from self- and cross-reactions of $\mathrm{RO}_{3}$ radicals in the atmosphere, Angew. Chemie. Int. Ed., 57, 3820-3824, https://doi.org/10.1002/anie.201710989, 2018a.

Berndt, T., Mentler, B., Scholz, W., Fischer, L., Herrmann, H., Kulmala, M., and Hansel, A.: Accretion Product Formation from Ozonolysis and $\mathrm{OH}$ Radical Reaction of $\alpha$-Pinene: Mechanistic Insight and the Influence of Isoprene and Ethylene, Environ. Sci. Technol., under review, 2018b.

Breitenlechner, M., Fischer, L., Hainer, M., Heinritzi, M., Curtius, J., and Hansel, A.: PTR3: An Instrument for Studying the Lifecycle of Reactive Organic Carbon in the Atmosphere, Anal. Chem., 89, 5824-5831, https://doi.org/10.1021/acs.analchem.6b05110, 2017.

Citroni, M., Ceppatelli, M., Bini, R., and Schettino, V.: Dimerization and polymerization of isoprene at high pressures, J. Phys Chem. B, 111, 3910-3917, https://doi.org/10.1021/jp0701993, 2007.

Compton, D. A. C., George, W. O., and Maddams, W. F.: Conformations of conjugated hydrocarbons. Part 1. A spectroscopic and thermodynamic study of buta-1,3-diene and 2-methylbuta-1,3-diene (isoprene), J. Chem. Soc., 2, 1666, https://doi.org/10.1039/p29760001666, 1976.

Duplissy, J., Merikanto, J., Franchin, A., Tsagkogeorgas, G., Kangasluoma, J., Wimmer, D., Vuollekoski, H., Schobesberger S., Lehtipalo, K., Flagan, R. C., Brus, D., Donahue, N. M., 
Vehkamäki, H., Almeida, J., Amorim, A., Barmet, P., Bianchi, F., Breitenlechner, M., Dunne, E. M., Guida, R., Henschel, H., Junninen, H., Kirkby, J., Kürten, A., Kupc, A., Määttänen, A., Makhmutov, V., Mathot, S., Nieminen, T., Onnela, A., Praplan, A. P., Riccobono, F., Rondo, L., Steiner, G., Tome, A., Walther, H., Baltensperger, U., Carslaw, K. S., Dommen, J., Hansel, A., Petäjä, T., Sipilä, M., Stratmann, F., Vrtala, A., Wagner, P. E., Worsnop, D. R., Curtius, J., and Kulmala, M.: Effect of ions on sulfuric acid-water binary particle formation: 2 . Experimental data and comparison with QC-normalized classical nucleation theory, J. Geophys. Res.-Atmos., 121, 1752-1775, https://doi.org/10.1002/2015JD023539, 2016.

Ehn, M., Thornton, J. A., Kleist, E., Sipilä, M., Junninen, H., Pullinen, I., Springer, M., Rubach, F., Tillmann, R., Lee, B., Lopez-Hilfiker, F., Andres, S., Acir, I.-H., Rissanen, M., Jokinen, T., Schobesberger, S., Kangasluoma, J., Kontkanen, J., Nieminen, T., Kurtén, T., Nielsen, L. B., Jørgensen, S., Kjaergaard, H. G., Canagaratna, M., Maso, M. D., Berndt, T., Petäjä, T., Wahner, A., Kerminen, V.-M., Kulmala, M., Worsnop, D. R., Wildt, J., and Mentel, T. F.: A large source of lowvolatility secondary organic aerosol, Nature, 506, 476-479, https://doi.org/10.1038/nature13032, 2014.

Eisele, F. L. and Tanner, D. J.: Measurement of the gas phase concentration of $\mathrm{H}_{2} \mathrm{SO}_{4}$ and methane sulfonic acid and estimates of $\mathrm{H}_{2} \mathrm{SO}_{4}$ production and loss in the atmosphere, J. Geophys. Res., 98, 9001-9010, https://doi.org/10.1029/93JD00031, 1993.

Estevez, Y., Gardrat, C., Berthelot, K., Grau, E., Jeso, B. de, Ouardad, S., and Peruch, F.: Unexpected dimerization of isoprene in a gas chromatography inlet. A study by gas chromatography/mass spectrometry coupling, J. Chromatography A, 1331, 133-138, https://doi.org/10.1016/j.chroma.2014.01.035, 2014.

Groves, S. and Lehrle, R.: Dimerisation of isoprene in a mass spectrometer source in GC-MS analysis, Polymer Degrad. Stab., 38, 183-186, https://doi.org/10.1016/0141-3910(92)90112-I, 1992.

Guenther, A. B., Jiang, X., Heald, C. L., Sakulyanontvittaya, T., Duhl, T., Emmons, L. K., and Wang, X.: The Model of Emissions of Gases and Aerosols from Nature version 2.1 (MEGAN2.1): An extended and updated framework for modeling biogenic emissions, Geosci. Model Dev., 5, 1471-1492, https://doi.org/10.5194/gmd-5-1471-2012, 2012.

Hallar, A. G., Lowenthal, D. H., Chirokova, G., Borys, R. D., and Wiedinmyer, C.: Persistent daily new particle formation at a mountain-top location, Atmos. Environ., 45, 4111-4115, https://doi.org/10.1016/j.atmosenv.2011.04.044, 2011.

Hallquist, M., Wenger, J. C., Baltensperger, U., Rudich, Y., Simpson, D., Claeys, M., Dommen, J., Donahue, N. M., George, C., Goldstein, A. H., Hamilton, J. F., Herrmann, H., Hoffmann, T., Iinuma, Y., Jang, M., Jenkin, M. E., Jimenez, J. L., KiendlerScharr, A., Maenhaut, W., McFiggans, G., Mentel, T. F., Monod, A., Prévôt, A. S. H., Seinfeld, J. H., Surratt, J. D., Szmigielski, R., and Wildt, J.: The formation, properties and impact of secondary organic aerosol: Current and emerging issues, Atmos. Chem. Phys., 9, 5155-5236, https://doi.org/10.5194/acp-9-51552009, 2009.

Heinritzi, M., Simon, M., Steiner, G., Wagner, A., C., Kürten, A., Hansel, A., and Curtius, J.: Characterization of the massdependent transmission efficiency of a CIMS, Atmos. Meas. Tech., 9, 1449-1460 https://doi.org/10.5194/amt-9-1449-2016, 2016.
Held, A., Nowak, A., Birmili, W., Wiedensohler, A., Forkel, R., and Klemm, O.: Observations of particle formation and growth in a mountainous forest region in central Europe, J. Geophys. Res.Atmos., 109, 23709, https://doi.org/10.1029/2004JD005346, 2004.

Jokinen, T., Berndt, T., Makkonen, R., Kerminen, V.-M., Junninen, H., Paasonen, P., Stratmann, F., Herrmann, H., Guenther, A. B., and Worsnop, D. R.: Production of extremely low volatile organic compounds from biogenic emissions: Measured yields and atmospheric implications, P. Natl. Acad. Sci., 112, 7123-7128, 2015.

Kanawade, V. P., Jobson, B. T., Guenther, A. B., Erupe, M. E., Pressley, S. N., Tripathi, S. N., and Lee, S.-H.: Isoprene suppression of new particle formation in a mixed deciduous forest, Atmos. Chem. Phys., 11, 6013-6027, https://doi.org/10.5194/acp11-6013-2011, 2011.

Khamaganov, V. G. and Hites, R. A.: Rate Constants for the GasPhase Reactions of Ozone with Isoprene, $\alpha$ - and $\beta$-Pinene, and Limonene as a Function of Temperature, J. Phys. Chem. A, 105, 815-822, https://doi.org/10.1021/jp002730z, 2001.

Kiendler-Scharr, A., Wildt, J., Dal Maso, M., Hohaus, T., Kleist, E., Mentel, T. F., Tillmann, R., Uerlings, R., Schurr, U., and Wahner, A.: New particle formation in forests inhibited by isoprene emissions, Nature, 461, 381-384, https://doi.org/10.1038/nature08292, 2009.

Kirkby, J., Curtius, J., Almeida, J., Dunne, E., Duplissy, J., Ehrhart, S., Franchin, A., Gagne, S., Ickes, L., Kürten, A., Kupc, A., Metzger, A., Riccobono, F., Rondo, L., Schobesberger, S., Tsagkogeorgas, G., Wimmer, D., Amorim, A., Bianchi, F., Breitenlechner, M., David, A., Dommen, J., Downard, A., Ehn, M., Flagan, R. C., Haider, S., Hansel, A., Hauser, D., Jud, W., Junninen, H., Kreissl, F., Kvashin, A., Laaksonen, A., Lehtipalo, K., Lima, J., Lovejoy, E. R., Makhmutov, V., Mathot, S., Mikkila, J., Minginette, P., Mogo, S., Nieminen, T., Onnela, A., Pereira, P., Petäjä, T., Schnitzhofer, R., Seinfeld, J. H., Sipilä, M., Stozhkov, Y., Stratmann, F., Tome, A., Vanhanen, J., Viisanen, Y., Vrtala, A., Wagner, P. E., Walther, H., Weingartner, E., Wex, H., Winkler, P. M., Carslaw, K. S., Worsnop, D. R., Baltensperger, U., and Kulmala, M.: Role of sulphuric acid, ammonia and galactic cosmic rays in atmospheric aerosol nucleation, Nature, 476, 429-433, https://doi.org/10.1038/nature10343, 2011.

Kirkby, J., Duplissy, J., Sengupta, K., Frege, C., Gordon, H., Williamson, C., Heinritzi, M., Simon, M., Yan, C., Almeida, J., Tröstl, J., Nieminen, T., Ortega, I. K., Wagner, R., Adamov, A., Amorim, A., Bernhammer, A.-K., Bianchi, F., Breitenlechner, M., Brilke, S., Chen, X., Craven, J., Dias, A., Ehrhart, S., Flagan, R. C., Franchin, A., Fuchs, C., Guida, R., Hakala, J., Hoyle, C. R., Jokinen, T., Junninen, H., Kangasluoma, J., Kim, J., Krapf, M., Kürten, A., Laaksonen, A., Lehtipalo, K., Makhmutov, V., Mathot, S., Molteni, U., Onnela, A., Peräkylä, O., Piel, F., Petäjä, T., Praplan, A. P., Pringle, K., Rap, A., Richards, N. A. D., Riipinen, I., Rissanen, M. P., Rondo, L., Sarnela, N., Schobesberger, S., Scott, C. E., Seinfeld, J. H., Sipilä, M., Steiner, G., Stozhkov, Y., Stratmann, F., Tomé, A., Virtanen, A., Vogel, A. L., Wagner, A. C., Wagner, P. E., Weingartner, E., Wimmer, D., Winkler, P. M., Ye, P., Zhang, X., Hansel, A., Dommen, J., Donahue, N. M., Worsnop, D. R., Baltensperger, U., Kulmala, M., Carslaw, K. S., and Curtius, J.: Ion-induced nucleation of pure biogenic parti- 
cles, Nature, 533, 521-526, https://doi.org/10.1038/nature17953, 2016.

Krechmer, J. E., Coggon, M. M., Massoli, P., Nguyen, T. B., Crounse, J. D., Hu, W., Day, D. A., Tyndall, G. S., Henze, D. K., Rivera-Rios, J. C., Nowak, J. B., Kimmel, J. R., Mauldin, R. L., Stark, H., Jayne, J. T., Sipilä, M., Junninen, H., Clair, J. M. S., Zhang, X., Feiner, P. A., Zhang, L., Miller, D. O., Brune, W. H., Keutsch, F. N., Wennberg, P. O., Seinfeld, J. H., Worsnop, D. R., Jimenez, J. L., and Canagaratna, M. R.: Formation of Low Volatility Organic Compounds and Secondary Organic Aerosol from Isoprene Hydroxyhydroperoxide Low-NO Oxidation, Environ. Sci. Technol., 49, 10330-10339, https://doi.org/10.1021/acs.est.5b02031, 2015.

Kubistin, D., Harder, H., Martinez, M., Rudolf, M., Sander, R., Bozem, H., Eerdekens, G., Fischer, H., Gurk, C., Klüpfel, T., Königstedt, R., Parchatka, U., Schiller, C. L., Stickler, A., Taraborrelli, D., Williams, J., and Lelieveld, J.: Hydroxyl radicals in the tropical troposphere over the Suriname rainforest: comparison of measurements with the box model MECCA, Atmos. Chem. Phys., 10, 9705-9728, https://doi.org/10.5194/acp10-9705-2010, 2010.

Kürten, A., Rondo, L., Ehrhart, S., and Curtius, J.: Performance of a corona ion source for measurement of sulfuric acid by chemical ionization mass spectrometry, Atmos. Meas. Tech., 4, 437-443, https://doi.org/10.5194/amt-4-437-2011, 2011.

Kürten, A., Rondo, L., Ehrhart, S., and Curtius, J.: Calibration of a chemical ionization mass spectrometer for the measurement of gaseous sulfuric acid, J. Phys. Chem. A, 116, 6375-6386, https://doi.org/10.1021/jp212123n, 2012.

Lee, S.-H., Uin, J., Guenther, A. B., Gouw, J. A. de, Yu, F., Nadykto, A. B., Herb, J., Ng, N. L., Koss, A., Brune, W. H., Baumann, K., Kanawade, V. P., Keutsch, F. N., Nenes, A., Olsen, K., Goldstein, A., and Ouyang, Q.: Isoprene suppression of new particle formation: Potential mechanisms and implications, J. Geophys. Res.-Atmos., 121, 14621-14635, https://doi.org/10.1002/2016JD024844, 2016.

Lelieveld, J., Butler, T. M., Crowley, J. N., Dillon, T. J., Fischer, H., Ganzeveld, L., Harder, H., Lawrence, M. G., Martinez, M., Taraborrelli, D., and Williams, J.: Atmospheric oxidation capacity sustained by a tropical forest, Nature, 452, 737-740, https://doi.org/10.1038/nature06870, 2008.

Lelieveld, J., Gromov, S., Pozzer, A., and Taraborrelli, D.: Global tropospheric hydroxyl distribution, budget and reactivity, Atmos. Chem. Phys., 16, 12477-12493, https://doi.org/10.5194/acp-1612477-2016, 2016.

Pierce, J. R., Westervelt, D. M., Atwood, S. A., Barnes, E. A., and Leaitch, W. R.: New-particle formation, growth and climaterelevant particle production in Egbert, Canada: Analysis from 1 year of size-distribution observations, Atmos. Chem. Phys., 14, 8647-8663, https://doi.org/10.5194/acp-14-8647-2014, 2014.

Pryor, S. C., Spaulding, A. M., and Barthelmie, R. J.: New particle formation in the Midwestern USA: Event characteristics, meteorological context and vertical profiles, Atmos. Environ., 44, 4413-4425, https://doi.org/10.1016/j.atmosenv.2010.07.045, 2010 .
Riipinen, I., Sihto, S.-L., Kulmala, M., Arnold, F., Dal Maso, M., Birmili, W., Saarnio, K., Teinilä, K., Kerminen, V.-M., Laaksonen, A., and Lehtinen, K. E. J.: Connections between atmospheric sulphuric acid and new particle formation during QUEST III-IV campaigns in Heidelberg and Hyytiälä, Atmos. Chem. Phys., 7, 1899-1914, https://doi.org/10.5194/acp-7-1899-2007, 2007.

Rissanen, M. P., Kurtén, T., Sipilä, M., Thornton, J. A., Kausiala, O., Garmash, O., Kjaergaard, H. G., Petäjä, T., Worsnop, D. R., Ehn, M., and Kulmala, M.: Effects of chemical complexity on the autoxidation mechanisms of endocyclic alkene ozonolysis products: From methylcyclohexenes toward understanding $\alpha$-pinene, J. Phys. Chem. A, 119, 4633-4650, https://doi.org/10.1021/jp510966g, 2015.

Taraborrelli, D., Lawrence, M. G., Crowley, J. N., Dillon, T. J., Gromov, S., Groß, C. B. M., Vereecken, L., and Lelieveld, J.: Hydroxyl radical buffered by isoprene oxidation over tropical forests, Nat. Geosci., 5, 190, https://doi.org/10.1038/ngeo1405, 2012.

Teng, A. P., Crounse, J. D., and Wennberg, P. O.: Isoprene Peroxy Radical Dynamics, J. Am. Chem. Soc., 139, 5367-5377, https://doi.org/10.1021/jacs.6b12838, 2017.

Tröstl, J., Chuang, W. K., Gordon, H., Heinritzi, M., Yan, C., Molteni, U., Ahlm, L., Frege, C., Bianchi, F., Wagner, R., Simon, M., Lehtipalo, K., Williamson, C., Craven, J. S., Duplissy, J., Adamov, A., Almeida, J., Bernhammer, A.-K., Breitenlechner, M., Brilke, S., Dias, A., Ehrhart, S., Flagan, R. C., Franchin, A., Fuchs, C., Guida, R., Gysel, M., Hansel, A., Hoyle, C. R., Jokinen, T., Junninen, H., Kangasluoma, J., Keskinen, H., Kim, J., Krapf, M., Kürten, A., Laaksonen, A., Lawler, M., Leiminger, M., Mathot, S., Möhler, O., Nieminen, T., Onnela, A., Petäjä, T., Piel, F. M., Miettinen, P., Rissanen, M. P., Rondo, L., Sarnela, N., Schobesberger, S., Sengupta, K., Sipilä, M., Smith, J. N., Steiner, G., Tomè, A., Virtanen, A., Wagner, A. C., Weingartner, E., Wimmer, D., Winkler, P. M., Ye, P., Carslaw, K. S., Curtius, J., Dommen, J., Kirkby, J., Kulmala, M., Riipinen, I., Worsnop, D. R., Donahue, N. M., and Baltensperger, U.: The role of low-volatility organic compounds in initial particle growth in the atmosphere, Nature, 533, 527-531, https://doi.org/10.1038/nature18271, 2016.

Walling, C. and Peisach, J.: Organic Reactions Under High Pressure. IV. The Dimerization of Isoprene 1, J. Am. Chem. Soc., 80 , 5819-5824, https://doi.org/10.1021/ja01554a058, 1958.

Yu, H., Ortega, J., Smith, J. N., Guenther, A. B., Kanawade, V. P., You, Y., Liu, Y., Hosman, K., Karl, T., Seco, R., Geron, C., Pallardy, S. G., Gu, L., Mikkilä, J., and Lee, S.-H.: New Particle Formation and Growth in an Isoprene-Dominated Ozark Forest: From Sub-5 nm to CCN-Active Sizes, Aerosol Sci. Technol., 48, 1285-1298, https://doi.org/10.1080/02786826.2014.984801, 2014. 